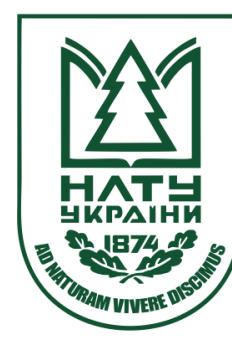

Науковий вісник НлтУ України Scientific Bulletin of UNFU

https://nv.nltu.edu.ua

https://doi.org/10.15421/40280905

$@ \bowtie$ Correspondence author

Article received 13.10.2018 p.

Article accepted 25.10.2018 p.

G. A. Lech

удк 330.331:305

gala1960@ukr.net

І. В. Ангелко, Г. А. Лех², Л. В. Рібун ${ }^{2}$

${ }^{1}$ Національний університет "Львівська політехніка", м. Львів, Україна

${ }^{2}$ Національний лісотехнічний університет Украӥни, м. Львів, Украӥна

\title{
ГЕНДЕРНА СЕГРЕГАЦІЯ - СТЕРЕОТИП ТА ПРОБЛЕМА СУЧАСНОГО РОЗВИТКУ ВІТЧИЗНЯНОГО РИНКУ ПРАЦІ
}

\begin{abstract}
Висвітлено основні аспекти гендерної сегрегації, визначено основні форми її поширення, чинники і причини існування на вітчизняному ринку праці. З'ясовано, що гендерна сегрегація певною мірою відображає нерівномірний розподіл працівників однієї статі між різними видами трудової діяльності на ринку праці та у сфері зайнятості, створюючи цим самим нерівномірність наповнення певного професійного середовища чоловіками та жінками. Встановлено, що існування та поширення гендерної сегрегації пов'язане 3 наявністю низки суспільних стереотипів щодо використання та застосування праці жінок і чоловіків у різних сферах та галузях трудової діяльності. Визначено, що гендерна сегрегація - це стереотип та проблема, яка притаманна сучасному розвитку вітчизняного ринку праці щодо зайняття жінками та чоловіками певної ніші у професійній чи галузевій піраміді. Установлено, що для вітчизняного ринку праці важливим $є$ питання впровадження дієвих заходів, що сприятимуть зміні суспільних стереотипів стосовно гендерного розподілу якості, рівня зайнятості та заробітної плати осіб двох статей. З'ясовано, що становище жінок на ринку праці України є менш сприятливим, ніж у чоловіків, насамперед через дію ринкового конкурентного механізму, наявність прямих бар'єрів для їх зайнятості, і як не дивно, репродуктивну функцію. Доведено, що на ринку праці України одночасно присутні стереотипи становища і поведінки, які дають змогу зберігати діючі механізми гендерної сегрегації, і наявність яких не дає змоги жінкам займати на рівні з чоловіками однакове становище.
\end{abstract}

Ключові слова: ринок праці; гендерна стратегія; зайнятість; працевлаштування; безробіття; сегрегаційні форми; горизонтальна та вертикальна сегрегація.

Вступ. Як відомо, упродовж останніх років однією 3 найактуальніших та найнагальніших проблем сучасності, яка "стоїть" на шляху ефективного розвитку вітчизняної економіки, залишається проблема зайнятості та працевлаштування. Ця проблема полягає не лише в скороченні зайнятості та посиленні тенденції тривалого безробіття серед різних верств населення, але й поширенні гендерної нерівності на ринку праці. Наприклад, як показує досвід, на вітчизняному ринку праці якість і рівень зайнятості чоловіків та жінок є різними, що зумовлено насамперед особливостями розвитку суспільства, притаманних йому соціально-економічних систем та стереотипів щодо існування та розвитку того чи іншого процесу.

Відомо, що в економічній практиці нерівномірний розподіл зайнятості між чоловіками та жінками у різних сферах та видах діяльності визначається як гендерна сегрегація. Проблеми існування та поширення гендерної сегрегації досліджено у працях багатьох вітчизняних учених, зокрема М. В. Ворони, О.В.Іващенка, І. В. Сфанової, Е. М. Лібанової, О. М. Лободинської, О. В. Макарова, Т. О. Марценюк, Т. М. Розумей, А. М. Фесенко та ін. Науковці у своїх працях значну увагу приділяють вивченню гендерних відмінностей та нерівностей на ринку праці, а також визначенню основних шляхів подолання гендерної дискримінації у зазначеній сфері.

Незважаючи на певні успіхи в дослідженні зазначеної проблеми, тема гендерної нерівності на ринку праці залишається актуальною, оскільки в суспільстві зберігається низка стереотипів щодо сучасного використання праці жінок і чоловіків.

Метою дослідження є висвітлення основних причин виникнення та існування гендерної сегрегації у різних сферах та галузях трудової діяльності в аспекті визначення окремих суспільних стереотипів щодо використання праці жінок і чоловіків, а також проблем ефективного розвитку вітчизняного ринку праці.

Викладення основного матеріалу. Насамперед потрібно зазначити, що гендерна сегрегація $є$ тенденцією стійкого розподілу чоловіків і жінок між різними сферами та галузями трудової діяльності, коли представники кожної статі з будь-яких причин зайняті на відмінних роботах, цим самим створюючи нерівномірність наповнення певного професійного середовища чоловіками та жінками. Інакше кажучи, в аспекті гендер-

\section{Інформація про авторів:}

Ангелко Ірина Володимирівна, канд. екон. наук, доцент. Email: Gala1960@ukr.net

Лех Галина Андріївна, канд. екон. наук, доцент, кафедра економічної теорії. Email: Gala1960@ukr.net

Рібун Любомир Володимирович, канд. екон. наук, доцент, завідувач кафедри економічної теорії. Email: Gala1960@ukr.net

Цитування за ДСТУ: Ангелко І. В., Лех Г. А., Рібун Л. В. Гендерна сегрегація - стереотип та проблема сучасного розвитку вітчизняного ринку праці. Науковий вісник Нлту України. Серія Економічна. 2018, т. 28, № 9. С. 31-34

Citation APA: Angelko, I. V., Lech, G. A., \& Ribun, L. V. (2018). Gender segregation as a stereotype and problem of the modern development in the domestic labour market. Scientific Bulletin of UNFU, 28(9), 31-34. https://doi.org/10.15421/40280905 
ної сегрегації, відбувається нерівномірний розподіл зайнятості між чоловіками та жінками у різних сферах та видах діяльності.

Враховуючи зазначене, очевидно, що в основі гендерної сегрегації лежить професійна сегрегація, яка, своєю чергою, сприяє "розвитку" різних сегрегаційних форм, зокрема галузевих, посадових, економіко-секторальних та ін. Відомо, що в економічній практиці за статевою ознакою розрізняють дві форми професійної сегрегації - горизонтальну та вертикальну. Як відомо, горизонтальна сегрегація вказує на розподіл чоловіків і жінок за професіями, галузями та видами трудової діяльності, вертикальна ж - за позиціями посадової ієрархії.

В аспекті цього поділу професійної сегрегації, доцільно зауважити, що всередині горизонтальної сегрегації $є$ також вертикальна вісь, адже професії відрізняються не лише за сутнісним принципом, але й за рівнем кваліфікації, певним організаційним статусом у професійному полі і навіть престижем тієї чи іншої професії (посади) (Ivashchenko \& Lobodynska, 2013, pp. 46).
Загалом горизонтальна та вертикальна сегрегації ринку праці - це причини нерівності між жінками і чоловіками, які створюють різні кар'єрні перспективи та соціальні можливості. Ці два механізми структурують ринок праці так, що жінки та чоловіки займають у ньому різні поверхи і ніші, формуючи так звану гендерну піраміду (Interviu, 2016).

Враховуючи світовий та вітчизняний досвід дослідження причин нерівномірного розподілу працівників однієї статі між різними видами діяльності, очевидно, що гендерна сегрегація може формуватися під впливом як зовнішніх обмежень (економічного та соціального характеру), так і індивідуального вибору працівником сфер свої професійної діяльності.

Як показує вітчизняна практика, сьогодні в Україні гендерна сегрегація пов'язана насамперед із показниками оплати праці. Відомо, що здебільшого на вітчизняному ринку праці заробітна плата чоловіків вища, ніж у жінок (табл. 1) (Statystyka, 2017).

Табл. 1. Середньомісячна заробітна плата жінок і чоловіків за видами економічної діяльності у 2018 р.*

\begin{tabular}{|c|c|c|c|c|}
\hline \multirow[t]{2}{*}{ Вид діяльності } & \multicolumn{2}{|c|}{$\begin{array}{c}\text { Нараховано в середньому, } \\
\text { грн }{ }^{* *}\end{array}$} & \multicolumn{2}{|c|}{$\begin{array}{c}\text { Різниця в оплаті праці чоловіка } \\
\text { та жінки }(+,-)\end{array}$} \\
\hline & жінці & чоловіку & грн & $\%$ \\
\hline Всього & 7800 & 9930 & +2130 & $+27,3$ \\
\hline $\begin{array}{l}\text { Сільське господарство, лісове господарство та рибне гос- } \\
\text { подарство }\end{array}$ & 6296 & 8120 & +1824 & $+29,0$ \\
\hline Промисловість & 7740 & 10359 & +2619 & $+33,8$ \\
\hline Будівництво & 6911 & 7693 & +782 & $+11,3$ \\
\hline $\begin{array}{l}\text { Оптова та роздрібна торгівля; ремонт автотранспортних за- } \\
\text { собів і мотоциклів }\end{array}$ & 8174 & 10373 & +2199 & $+26,9$ \\
\hline $\begin{array}{l}\text { Транспорт, складське господарство, поштова та кур'єрська } \\
\text { діяльність }\end{array}$ & 8011 & 10549 & +2538 & $+31,7$ \\
\hline Тимчасове розміщування й організація харчування & 5516 & 6335 & +819 & $+14,9$ \\
\hline Інформація та телекомунікації & 12799 & 16024 & +3225 & $+25,2$ \\
\hline Фінансова та страхова діяльність & 13265 & 20562 & +7297 & $+55,0$ \\
\hline Операції з нерухомим майном & 6471 & 7551 & +1080 & $+16,7$ \\
\hline Професійна, наукова та технічна діяльність & 11113 & 13300 & +2187 & $+19,7$ \\
\hline $\begin{array}{l}\text { Діяльність у сфері адміністративного та допоміжного об- } \\
\text { слуговування }\end{array}$ & 6966 & 7019 & +53 & $+0,8$ \\
\hline $\begin{array}{l}\text { Державне управління й оборона; обов'язкове соціальне } \\
\text { страхування }\end{array}$ & 12029 & 12749 & +720 & $+6,0$ \\
\hline Освіта & 7323 & 7438 & +115 & $+1,6$ \\
\hline Охорона здоров'я та надання соціальної допомоги & 5692 & 6437 & +745 & $+13,1$ \\
\hline Мистецтво, спорт, розваги та відпочинок & 6215 & 11514 & +5299 & $+85,3$ \\
\hline Надання інших видів послуг & 7261 & 8651 & +1390 & $+19,1$ \\
\hline
\end{tabular}

Примітка: * Складено за даними (Statystyka, 2017). ** Дані наведено за другий квартал 2018 р.

Загалом, згідно з наведеними статистичними даними (див. табл. 1), середня заробітна плата чоловіків є вищою від середньої заробітної плати жінок, у середньому по всіх галузях та сферах діяльності, більш ніж на чверть (у другому кварталі 2018 р. цей показник становив 27,3 \%). Зокрема, понад 50 \%, а це значна різниця в оплаті праці жінок і чоловіків, спостерігається у сферах мистецтва, спорту, розваг та відпочинку, а також у фінансовій і страховій сферах; незначна (до $5 \%$ - у сферах адміністративного та допоміжного обслуговування, освіти та соціальної допомоги. У контексті виділення галузей і сфер діяльності з високим та низьким рівнем оплати праці, варто зазначити, що саме незначна різниця в оплаті праці жінок і чоловіків дає підстави стверджувати про існування все ж таки певної рівності серед зайнятих осіб обох статей.

Доцільно також зауважити, що істотна різниця в оплаті праці жінок і чоловіків пов'язана передусім 3 наяв- ністю у суспільстві стереотипів щодо їх місця та ролі. Так, незважаючи на формально рівні можливості обох статей, на вітчизняному ринку праці існує безліч неформальних, "невидимих" бар'єрів, що перешкоджають просуванню жінок по щаблях посадової ієрархії. Як відомо, жінки довше затримуються на початкових позиціях службової ієрархії (що здебільшого пов'язано з материнством), тоді як чоловіки просуваються на наступні щаблі службової "драбини", що забезпечує їм формування необхідного професійного та управлінського досвіду, який загалом дає змогу випередити жінок у занятті вищих керівних посад.

Однак різниця в оплаті праці жінок і чоловіків не $\epsilon$ єдиним чинником виникнення та існування гендерної сегрегації на вітчизняному ринку праці. Упродовж останніх років вагомим чинником "присутності" та поширення гендерної сегрегації на вітчизняному ринку праці залишається також стереотип щодо гендерного поділу 
професій (чи окремих посад) на суто жіночі та суто чоловічі (Tsentr Razumkova, 2016). Так, у вітчизняному суспільстві існує стереотип, згідно з яким за жінками "закріплені" ті сфери діяльності, які не вимагають великого фізичного навантаження, стійкої витривалості, здібностей до швидкого мислення, точних і природничих наук, логіки та зосередження, що загалом зумовлює їхню нездатність працювати на високих керівних посадах, а отже, й отримувати вищу заробітну плату. Згідно 3 цим стереотипом, основними сферами для діяльності жінок повинні бути ті, що пов'язані з піклуванням, вихованням, навчанням, а також ті професії, які вимагають застосування у роботі дрібної моторики (сфери соціального забезпечення, освіти, охорони здоров'я, побутового обслуговування та культури тощо).

Загалом, варто відзначити, що становище жінок на ринку праці України є менш сприятливим, ніж у чоловіків, насамперед через дію ринкового конкурентного механізму, наявність прямих бар'єрів для їх зайнятості (вужчий професійний вибір, відсутність потрібних для них робочих місць або потрібної кваліфікації), і як не дивно, репродуктивну функцію. Саме через останню, досить часто, деякі роботодавці сприймають і розглядають працю жінок як менш корисну та ефективну, оскільки жінкам доводиться поєднувати професійну діяльність із материнством та сімейними обов'язками. Це, своєю чергою, породжує певний стереотип поведінки у самих жінок-працівниць, адже вони, знаючи про упереджене ставлення до себе як працівника з боку роботодавця, не прагнуть чогось більшого, погоджуються на заздалегідь невигідні, з огляду оплати праці, умови або на роботу без визначеного графіку, або роботу без видимого кар'єрного чи професійного просування, або інші обмеження (Ivashchenko \& Lobodynska, 2013, pp. 49). Така ситуація доводить, що на ринку праці України одночасно присутні стереотипи становища (з боку роботодавця - дискримінація) і поведінки (з боку жінки-працівниці - самообмеження), які дають змогу зберігати діючі механізми гендерної сегрегації, і наявність яких не дає змоги жінкам займати на рівні з чоловіками однакове становище.

Про "несприятливе" становище жінок на вітчизняному ринку праці свідчать також статистичні дані (табл. 2), відповідно до яких економічна активність та зайнятість чоловіків є вищими, ніж у жінок (на 11,9 та 9,2 \% відповідно).
Табл. 2. Показники економічної активності та зайнятості жінок і чоловіків у 2018 р. *

\begin{tabular}{|c|c|c|c|c|}
\hline \multirow[b]{2}{*}{ Показник } & \multicolumn{2}{|c|}{ Жінки** } & \multicolumn{2}{|c|}{ Чоловіки** } \\
\hline & тис. осіб & $\begin{array}{c}\text { у \% до } \\
\text { всього } \\
\text { населення }\end{array}$ & $\begin{array}{l}\text { тис. } \\
\text { осіб }\end{array}$ & $\begin{array}{c}\text { у \% до } \\
\text { всього } \\
\text { населення }\end{array}$ \\
\hline $\begin{array}{l}\text { Економічна } \\
\text { активність }\end{array}$ & 8543,7 & 56,7 & 9339,9 & 68,6 \\
\hline Зайнятість & 7898,1 & 52,4 & 8385,1 & 61,6 \\
\hline
\end{tabular}

Примітка: * Складено за даними (Rynok pratsi, 2018).

** Дані наведено за перше півріччя 2018 р.

Висновок. Підсумовуючи, доцільно зазначити, що гендерна сегрегація передусім відображає нерівномірний розподіл працівників однієї статі між різними видами трудової діяльності на ринку праці та у сфері зайнятості. Її існування та поширення пов'язане з наявністю цілої низки суспільних стереотипів щодо використання та застосування праці жінок і чоловіків у різних сферах та галузях трудової діяльності (жінки, зазвичай, зайняті на низькооплачуваних роботах, чоловіки ж навпаки на високооплачуваних).

Гендерна сегрегація $є$ певною мірою стереотипом, який притаманний сучасному розвитку вітчизняного ринку праці щодо зайняття жінками та чоловіками певної ніші у професійній чи галузевій піраміді.

Для України, яка перебуває на шляху євроінтеграційних трансформацій, дуже важливим є питання впровадження дієвих заходів, що сприятимуть зміні суспільних стереотипів стосовно гендерного розподілу якості, рівня зайнятості та заробітної плати на вітчизняному ринку праці серед осіб обох статей.

\section{Перелік використаних джерел}

Interviu. (2016). Pro stereotypy na rynku pratsi, samodyskryminatsiiu, yak vykhovaty zhinok-lideriv ta chomu cholovikam platiat bilshe: interviu z sotsiolohyneiu Tamaroiu Martseniuk. The Point: onlainzhurnal. Retrieved from: https://thepoint.rabota.ua/pro-stereotypnyy-rynok-pratsi-samodyskrymnatsiyu-yak-vyhovaty-zhinoklideriv-ta-chomu-cholovikam-platyat-bilshe-intervyu-z-sotsiolohyneyu-tamaroyu-martsenyuk/. [In Ukrainian].

Ivashchenko, O. V., \& Lobodynska, O. M. (2013). Henderna sehrehatsiia chy henderna asymetriia na rynku pratsi: teoretychni zasady ta empirychni proiavy pry pratsevlashtuvanni v Ukraini. Ukrainskyi sotsium, 1(44), 43-62. [In Ukrainian].

Rynok pratsi. (2018). Retrieved from: http://www.ukrstat.gov.ua/. [In Ukrainian].

Statystyka. (2017). Demohrafichna ta sotsialna statystyka. Retrieved from: http://www.ukrstat.gov.ua/. [In Ukrainian].

Tsentr Razumkova. (2016). Henderna rivnist i rozvytok: pohliad u konteksti Yevropeiskoi stratehii Ukrainy. Retrieved from: http://www.razumkov.org.ua/upload/Gender-FINAL-S.pdf. [In Ukrainian].

И. В. Ангелко ${ }^{1, \text { Г. А. Лех², Л. В. Рибун }}{ }^{2}$

${ }^{1}$ Национальный университет "Львовская политехника", г. Львов, Украина

${ }^{2}$ Национальный лесотехнический университет Украинь, г. Львов, Украина

\section{ГЕНДЕРНАЯ СЕГРЕГАЦИЯ - СТЕРЕОТИП И ПРОБЛЕМА СОВРЕМЕННОГО РАЗВИТИЯ}

ОТЕЧЕСТВЕННОГО РЫНКА ТРУДА

Рассмотрены основные аспекты гендерной сегрегации, определены основные формы ее распространения, факторы и причины существования на отечественном рынке труда. Выяснено, что гендерная сегрегация в определенной степени отражает неравномерное распределение работников одного пола между различными видами трудовой деятельности на рынке труда и в сфере занятости, создавая тем самым неравномерность наполнения определенной профессиональной среды мужчинами и женщинами. Установлено, что существование и распространение гендерной сегрегации связано с наличием целого ряда общественных стереотипов относительно использования и применения труда женщин и мужчин в различных сферах и отраслях трудовой деятельности. Определено, что гендерная сегрегация представляет собой стереотип и проблему, которая присуща современному развитию отечественного рынка труда относительно занятия женщинами и мужчинами определенной ниши в профессиональной или отраслевой пирамиде. Установлено, что для отечественного рынка труда важным яв- 
ляется вопрос внедрения действенных мер, способствующих изменению общественных стереотипов относительно гендерного распределения качества, уровня занятости и заработной платы лиц двух статей. Установлено, что положение женщин на рынке труда Украины является менее благоприятным, чем у мужчин, прежде всего из-за действия рыночного конкурентного механизма, наличие прямых барьеров для их занятости (узкий профессиональный выбор, отсутствие необходимых для них рабочих мест или необходимой квалификации), и как ни странно, репродуктивную функцию. Именно через последнюю, достаточно часто, некоторые работодатели воспринимают и рассматривают труд женщин как менее полезный и эффективный, поскольку женщинам приходится совмещать профессиональную деятельность с материнством и семейными обязанностями. Это, прежде всего, порождает определенный стереотип поведения в самих женщин-работниц, ведь они, зная о предвзятом отношении к себе как работника со стороны работодателя, не хотят чего-то большего, соглашаются на заранее невыгодные, учитывая оплату труда, условия или на работу без определенного графика, или работу без видимого карьерного или профессионального продвижения, или другие ограничения. Доказано, что на рынке труда Украины одновременно присутствуют стереотипы положения (со стороны работодателя - дискриминация) и поведения (со стороны женщины-работницы - самоограничение), которые позволяют сохранять действующие механизмы гендерной сегрегации, и наличие которых не позволяет женщинам занимать наравне с мужчинами одинаковое положение.

Ключевые слова: рынок труда; гендерная стратегия; занятость; трудоустройство; безработица; сегрегационные формы; горизонтальная и вертикальная сегрегация.

\author{
I. V. Angelko', G. A. Lech', L. V. Ribun' \\ ${ }^{I}$ Lviv Polytechnic National University, Lviv, Ukraine \\ ${ }^{2}$ Ukrainian National Forestry University, Lviv, Ukraine
}

\title{
GENDER SEGREGATION AS A STEREOTYPE AND PROBLEM OF THE MODERN DEVELOPMENT IN THE DOMESTIC LABOUR MARKET
}

The article covers the main aspects of gender segregation, and also defines the main forms of its dissemination, factors and causes of its existence in the domestic labour market. Gender segregation is revealed to reflect to a certain extent the uneven distribution of employees of the same gender between different types of labour activity in the labour market and in the sphere of employment, thereby creating unevenness in the filling of a certain professional environment by men and women. The authors have found that the existence and distribution of gender segregation is associated with the presence of a number of social stereotypes regarding the use and application of the male and female labour in various spheres and branches of labour activity. Gender segregation is determined to be a stereotype and a problem that is inherent in the contemporary development of the domestic labour market in relation to the occupation of male and female employees of a specific niche in a professional or sectorial pyramid. The market is proved to be important for introducing effective measures for the domestic labour promoting changes in public stereotypes concerning the gender distribution of quality, the level of employment and wages of the representatives of the two genders. It is found that female position in the labour market of Ukraine is less favourable than male position because of the market competitive mechanism, the presence of direct barriers for their employment, and strangely enough because of this reproductive function. Due to the latter reason, some employers often consider female work as less useful and effective, since females have to combine their professional activities with maternity and family responsibilities. That in turn causes a certain stereotype in the working female behaviour as they, being aware of employers' prejudicial attitude, do not strive to achieve something in their life. They are ready in advance to accept any unfavourable offers, concerning their wages, working conditions without defined working hours and visible career promotion or the other restriction of women's rights. Thus, the stereotype of position (discrimination created by the employer) and behaviour (self-restriction created by a working woman) is proved to appear simultaneously on the labour market of Ukraine, which allows maintaining operating mechanisms of gender segregation and the presence of which does not provide possibility to occupy the same positions for women and men.

Keywords: labour market; gender segregation; employment; unemployment; segregation forms; horizontal and vertical segregation. 